\title{
MINORITY RIGHT TO ATTEND RELIGIOUS EDUCATION IN INDONESIA
}

\author{
Raihani \\ Sultan Syarif Kasim State Islamic University (UIN Suska) Riau, \\ Indonesia \\ email:r41b4n1@gmail.com
}

\section{Abstract}

In 2003, Indonesian government issued a new education law in which one of the articles (Article 12) states that student has the right to access religion class in school in accordance with his or her religion by teachers who share the faith. This particular article has a legal ramification that school--state and private-- by law must provide corresponding Religion Classes (RC) for each religious group of students in order to fulfil their very buman basic right to access to and observe their religious and cultural teaching and practices. This paper presents findings of four different school case studies on the problem of access to $\mathrm{RC}$ by religious minority in schools in Indonesia. Minority in this paper refers to religious groups that are either numeric minority or subordinate majority at the micro school level, not in the macro national population. This paper argues that numeric minority in any context (micro or macro) is vulnerable to discrimination by the dominating majority when the law of social relations is not fairly implemented. The findings suggest that the right of religious minority groups in three of the four schools to access proper $\mathrm{RC}$ is stifled, particularly to access equal learning facilities. Numeric religious minority groups in these schools suffer from powerlessness. One case, however, demonstrates that the positional power of minority group reverses this logic of minority-powerlessness and puts the religious majority students in a subordinate position.

Tabun 2003, pemerintah Indonesia mengeluarkan Undang-Undang Pendidikan yang pada pasal 12 menyatakan bahwa siswa mempunyai hak terhadap pelajaran agama di sekolah dengan guru yang mengajar sesuai dengan agamanya. Pasal ini mempunyai konsekuensi bahwa sekolah, baik 
swasta atau pun negeri, harus menyediakan kelas agama untuk setiap kelompok siswa untuk mendapatkan hak dasarnya guna melaksanakan agama dan ajarannya. Artikel ini menampilkan hasil penelitian dari empat sekolah dengan studi kasus pada persoalan kelas agama bagi kelompok minoritas. Istilah minoritas di sini merujuk pada kelompok agama yang sedikit jumlahnya atan kelompok kecil pada sekolah, bukan pada level nasional. Tulisan ini menegaskan bahwa minoritas pada konteks mikro atau makro sangat rentan terhadap perlakuan diskriminasi oleb kelompok mayoritas ketika bukum social tidak sepenubnya dijalankan. Penemuan ini menegaskan bahwa hak keagamaan minoritas dalam tiga dari empat sekolah terganggu, terutama yang terkait dengan hak fasilitas belajar. Beberapa kelompok minoritas pada sekolah tersebut tak berdaya. Namun, satu kasus menunjuk.kan babwa kondisi minoritas berbalik, justru kelompok mayoritas yang menjadi subordinasi.]

Keywords: religious minority rights, religion classes, secondary schools, minority-majority relations

\section{A. Introduction}

This present study is part of a larger team-research project on education for multicultural and tolerant Indonesia funded by Australia Research Council (ARC). One of the concerns in this larger research has been the religion classes in the schools studied: why they should be taught, how they are imparted and evaluated in both public and private schools, what factors that support or impede their implementation, and how religious groups are treated in terms of getting access to the classes and facilities. While all of the issues listed earlier are important, the last issue of religious minority access to religion class warrants a special analysis. This issue is highly relevant to particularly Article 12 of the Education Law of 2003, which mandates that student has the right to access religion class in school in accordance with his or her religion by teachers who share the faith. This issue also corresponds to a long-standing problem of minority rights to access equal treatment and public service in Indonesia including religious education. This important issue does not only depict how the Indonesian Muslim majority state manages to fulfil the rights of religious minority and to facilitate positive relationships between minority and majority, but it describes also how actually private institutions respond to the basic human rights of the religious minority. 
This paper, therefore, presents findings of four different case studies on the problem of access to Religion Classes (RC) by religious minority in schools in Indonesia. The main question it poses is whether the rights of religious minority in access to RC in the four schools are granted, how they are granted, and what factors influence the granting of such religious minority rights. What I mean by minority here does not refer to the religious numeric minority population of the macro Indonesia that include all non-Muslims. Minority in this paper refers to religious groups that are either numeric minority or subordinate majority at the micro school level. Numeric minority refers to religious groups whose members are significantly fewer in statistics than the rest of the school population. Subordinate majority means that any religious group whose members are majority in numbers but because of lack of power and status they are subordinate to the minority groups. These groups could be Muslim and Hindu students in Christian schools, Christians and Hindus in Islamic schools, or a religious minority group in a public school. It is possible that this group is minority in school but majority in community like Muslim students in Catholic schools or otherwise. The composition of the religious groups in each school will be conveyed later in the methodology section.

I am convinced that this research is important because there has been lack of attention to the issue of religious minority rights in the contexts of micro environment like schools. Much research and media attention have so far been on the issues of religious numeric minority in the context of macro Indonesia. ${ }^{1}$ There is nothing wrong with this vast research and media interest since Indonesia has had a big problem in dealing with the religious and other minorities. While this macro issue is important, the status of minority in a micro school environment has its particular significance as I discussed in the first paragraph above. This paper is in no way intended to pull our look totally from the macro issues, instead, it complements the so-far research on the issues of religious minority groups in Indonesia. Also, as this paper is based on "only" four case studies, I shall remind that its generalizability is limited. In other words, other state and private schools in Indonesia may display different

${ }^{1}$ Endy Bayuni, Blood Blasphemy: Antagonising Religious Minorities in Indonesia and Pakistan, Report, no. 27 (New York: Washington D.C. East-West Center, 2011); Melissa Crouch, "Regulation on Places of Worship in Indonesia: Upholding the Right to Freedom of Religion for Religious Minorities?", Singapore Journal of Legal Studies, vol. 2007 (2010), pp. 96-116. 
pictures of how religious minority access RC.

In this paper, I briefly review the relevant literature on the issues of minority groups to identify what rights inherently belong to them and how their rights to RC are granted in practices in several contexts. Next, I describe the methodology of the study including the very brief profile of each of the four schools. I continue to present research findings of how religious minority access to $\mathrm{RC}$ in these schools followed by further discussions

\section{B. Religious Minority Rights and RC}

The post-colonial era has witnessed the continuing massive migration of people of the Third World to what-so-called more developed countries. Civil wars and quest for better life are often cited for such people movement. This migration has constructed a new society in the host countries where there is no longer one single culture that exists and dominates. ${ }^{2}$ The new society now consists of various ethnics and cultures which signify more complex relationships among people and between people and the state. Tensions, frictions, and conflicts have often occurred because of the complex construction of society. Some conflicts are purely triggered by cultural incompatibilities among groups, but some others are politically and economically ignited. To anticipate and/or overcome these problems, in some countries the idea of people living together in harmony based on mutual understanding, fairness, equality and social justice has emerged. This idea is often termed as multiculturalism in which much of the proportion of concerns is dominated by the issue of minority rights. ${ }^{3}$

Minority is a contested concept particularly in regards to which group is considered as minority. For the United Nations, minority is defined as:

A group numerically inferior to the rest of the population of a State, in a non-dominant position, whose members-being nationals of the State-possess ethnic, religious or linguistic characteristics differing

${ }^{2}$ Commonweath of Australia, Multicultural Australia: United in Diversity, Updating the 1999 New Agenda for Multicultural Australia, Strategic Directions for 2003-2006 (Canberra: Dept. of Immigration and Multicultural and Indigenous Affairs, 2003), pp. 2003-6; Bhikhu Parekh, Rethinking Multiculturalism: Cultural Diversity and Political Theory, $2^{\text {nd }}$ ed. (New York: Palgrave Macmillan, 2005).

${ }^{3}$ Will Kymlicka, Multicultural Citizenship: A Liberal Theory of Minority Rights (New York: Oxford University Press, 1995); Stephen Macedo, Diversity and Distrust: Civic Education in a Multicultural Democracy (Cambridge: Harvard University Press, 1999). 
from those of the rest of the population and show, if only implicitly, a sense of solidarity, directed towards preserving their culture, traditions, religion or language. ${ }^{4}$

The above definition explicitly refers to the numeric minority of ethnic, religious, or linguistic backgrounds. This minority is often characterised by powerlessness, injustice, discrimination and marginalisation. As Schaefer ${ }^{5}$ is concerned, in some situations numeric majority can also experience subordination to the minority which usually holds the power of domination. This subordinate majority is similarly attributed with oppression and marginalisation. The Shi'i community in Bahrain is a clear example of the majority under oppression of the Sunni minority. Their rights to be equal citizens who freely enjoy their culture, traditions, religions or language are restricted and not recognised. Charles Taylor, ${ }^{6}$ therefore, argues for the importance of the politics of recognition toward the rights of these powerless groups for misrecognition or nonrecognition of these groups and their rights can lead to oppression, subordination and discrimination to them.

As ethnic minority issues such as indigenous Aboriginal people in Australia and African American people in the US have overwhelmed the debates around multiculturalism, religious minority has equally attracted attention. Religious minority groups are often described to have suffered from lack of recognition, unequal treatment, and the infringement of rights to observe their religious teachings and practices. For example, female Muslims in the Western secular countries like France have faced a serious problem in relation to their commitment to wear Islamic veils in public spaces. ${ }^{7}$ In France, too often Islam and Muslims are perceived as social problems rather than as citizens who have equal rights and

${ }^{4}$ United Nations, Minority Rights: International Standards and Guidance for Implementations (New York: United Nations, Human Rights Office of the High Commissioner, 2010), p. 2.

5 Richard T. Schaefer, Racial and Ethnic Groups (New York: Longman, 1998).

${ }^{6}$ Charles Taylor, "The Politics of Recognition", in Multiculturalism: Examining the Politics of Recognition, ed. by Amy Gutmann (New York: Princeton University Press, 1994), pp. 25-73.

${ }_{7}$ France in 2011 officially banned women from wearing full-face veils in public places. The right wings in other European countries like Netherlands and Italy have proposed similar banning, see "France Bans the Burqa", SBS.com (29 Aug 2013), http:// www.sbs.com.au/news/article/2011/04/11/france-bans-burqa, accessed 23 Oct 2013. Al-Jämi'ah, Vol. 53, No. 1, 2015 M/1436 H 
responsibilities. ${ }^{8}$ In many Muslim countries, like Saudi Arabia, Egypt, Malaysia and to some extent Indonesia, non-Muslims have also been faced with religious and citizenship discriminations. There are restrictions of building Churches, using "Allah" in the Bible, and fully participating in politics. All of these instances indicate that religious minority groups have remained to suffer from discrimination and marginalisation by the dominating group.

In 1992 the United Nations Minorities Declaration by consensus (resolution 47/135) was issued and this declaration has become the main reference document for minority rights. ${ }^{9}$ In this document, as summarised in one of the High Commissions document, minority groups have the rights to be protected, to enjoy their own culture, to profess and practise their own religion, and to use their own language in private and in public. They are entitled to participate effectively in cultural, religious, social, economic and public life, to participate effectively in decisions which affect them on the national and regional levels, and to establish and maintain their own associations, to establish and maintain peaceful contacts with other members of their group. They also have the freedom to exercise their rights, individually as well as in community with other members of their group, without discrimination. To ensure these rights are protected, the United Nations obliged states to take necessary measures.

While the above list of rights refers to any minority group in any state of the world, specifically for religious minority groups the International Covenant on Civil and Political Rights adopted by the United Nations mandates that "The States Parties to the present Covenant undertake to have respect for the liberty of parents and, when applicable, legal guardians to ensure the religious and moral education of their children in conformity with their own convictions". ${ }^{10}$ This mandate guarantees the right of religious minority to access their own religious teachings in order to preserve faiths and cultures of their own. In some secular countries like the USA, France, and Netherlands, religious minority can access to RC in private schools or Churches. In the UK, although RC

${ }^{8}$ Jocelyn Cesari, "Islam in France: The Shaping of a Religious Minority", in Muslims in the West, from Sojourners to Citizens, ed. by Yvonne Yazbeck Haddad (New York: Oxford University Press, 2002), pp. 36-51.

9 United Nations, Minority Rights, p. 14.

${ }^{10}$ UN General Assembly, International Covenant on Civil and Political Rights, vol. 999 (United Nations Treaty Series, 2012), p. 171, http://www.refworld.org/cgi-bin/ texis/vtx/rwmain?docid=3ae6b3aa0, accessed 30 Jan 2015. 
is compulsory in schools, minority groups particularly Muslims are not satisfied with the provision of RC because the lessons are designed for all religions, not specifically for particular religions. ${ }^{11}$ In Indonesia, the rights of minority groups are protected by law to have $\mathrm{RC}$ in both public and private schools at all levels of education. Their rights are granted by the constitution and strengthened by the Education Law of $2003 .^{12}$

The compulsory status of RC in Indonesia is in fact not exclusively required by the Education Law of 2003, but was mandated in several previous laws. Yet, in history, before 1965, RC was made an optional or non-compulsory subject. In the Education Law of 1950, religion class was to be carried out selectively depending on the age and intellectual level of students; students have freedom whether to follow religion class; and religion class was made as a non-determinant subject to grade promotion. ${ }^{13}$ This was at that time seen as a middle way between the Muslim demand to have a compulsory religion class and the secular group's and Christian's view to have state schools free from that class. ${ }^{14}$ The political rivalry between the military and the communist between 1960 and 1965 contributed to the affirmation of religion class as a compulsory subject in 1965. The communist wanted to demolish religion class from schools. The military, opposing the communist's ideas including this one, invited Islamists to promote religion class as a compulsory subject. The failed coup of the communist in 1965 gave the military a stronger position in Indonesian politic, and the idea of making religion class as a compulsory subject was eventually realised in 1965. Subsequently, the temporary People General Assembly (MPRS) issued the Decree No. XXVII/1966 declaring the compulsory status of religion

11 Peter Mandaville, "Islamic Education in Britain: Approaches to Religious Knowledge in a Pluralistic Society", in Schooling Islam: The Culture and Politics of Modern Muslim Education, ed. by Robert W. Hefner and Muhammad Qasim Zaman (New Jersey: Princeton University Press, 2007), pp. 224-41.

${ }^{12}$ Listia, Laode Arham, and Lian Gogali, Problematika Pendidikan Agama di Sekolah: Hasil Penelitian tentang Pendidikan Agama di Kota Jogjakarta, 2004-2006 (Yogyakarta: Interfidei/Dian, 2007); also see Raihani, "Religion Classes in Indonesia: Translating Policy into Practice", presented at the the Crises and Opportunities: Proceedings of the 18th Biennial Conference of the ASAA (Adelaide: University of Adelaide, 8 May 2010).

13 Mujiburrahman describes the change of RC status over the period of early Indonesian independence, the Old and New Orders; Mujiburrahman, Feeling Threatened: Muslim-Christian Relations in Indonesia's New Order (Amsterdam: Amsterdam University Press; ISIM, 2006), pp. 227-30, in particular.

${ }^{14}$ Lambert Kelabora, "Religious Instruction Policy in Indonesia", Asian Survey, vol. 16, no. 3 (1976), pp. 230-48. 
class from primary to university. Again preceded by a hot debate in the parliament between the secular proponents and Islamists, the Education Law of 1989 reasserted the status of religion as a compulsory subject in Indonesian schools. ${ }^{15}$

$\mathrm{RC}$ continues to be compulsory in the school curriculum and this status is reasserted in the Education Law of $2003 .{ }^{16}$ While the debate surrounding the previous laws was concerned with the status of religion class - whether it is compulsory or not, it was now regarding the obligatory requirement of school to provide religious teaching for pupils in accordance with their own faith and by teachers who share the faith. The opponent of this law, notably Christian groups and some Muslim activists, argued that the law would create segregation among religious groups in school and consequently in society. Their further concerns were particularly in regards to (mostly, not to say all) private Christian schools which would, under the law, have to provide the Islamic religion class for minority Muslim students. The Muslim proponents of the law rejected the above argument of social segregation because diversity of RC in one school does not lead segregation, and it is the fact that Indonesia is diverse. According to Listia et al., ${ }^{17}$ the Hindus community in Bali also supported this law for their own interest because many of Hindu children go to Christian schools. They said that teaching students religions other than their own faith would even suggest school's intolerance to religious differences, and fail to create security in students and parents about their faiths. Adian Husaini, a notable Islamist, took an example that private Muslim schools such as Muhammadiyah schools in Kupang had provided Christian religion classes for Christian students to ensure their religious rights. He said: "If Muslims are willing to do so, why are not Christians?"18 After all, this particular regulation remains part of the Law when it was issued in 2003.

I personally believe that Article 12 of the Education Law of 2003 stating that every student has the right to access RC according to his or her own religion responds well to the basic human rights of individuals to access to religious education as mentioned earlier. The article of the law

15 Mujiburrahman, Feeling Threatened.

${ }^{16}$ Departemen Pendidikan Nasional, Undang-Undang Sistim Pendidikan Nasional Tahun 2003 (2003), http:/ / www.depdiknas.go.id, accessed 8 Oct 2003.

${ }^{17}$ Listia, Laode Arham, and Lian Gogali, Problematika Pendidikan Agama di Sekolah.

18 Adian Husaini, "Membela Pendidikan Agama", Republika Jakarta, 15 Mar 2003), https://groups.yahoo.com, accessed 15 Jan 2005. 
does not only think of the minority rights to access religious education at the macro level, but also ensures to grant their rights to do so at the micro school level. There may be individuals or groups who adopt secular beliefs that religion is a private matter so that the state may not intervene in, or may be individuals who confess to atheism, and hence does not need religious education. For these individuals and groups, the law indeed does not grant their rights to opt out RC. Complying with the underpinning legal principles in Indonesia, the law implies that every Indonesian individual is required to have a faith in one of the acknowledged religions. Therefore, the question of whether to have religious education or not should be addressed to the state's constitution provides a clear political framework that Indonesia is based on the principle of "Ketuhanan Yang Maha Esa" (monotheism).

\section{The Four Case Studies}

The fieldwork of the study was conducted from 2009 to 2010. This is a qualitative study ${ }^{19}$ of four different senior secondary schools: Creativity in Yogyakarta, Rose Garden, Averroes and St Peter in Central Kalimantan. The first two mentioned schools are state schools, while the last two are private (one Islamic and the other Catholic). Creativity was one of the best vocational schools in the Yogyakarta province enrolling around 850 students in 2009. The majority of students were Muslims with only about 20 Christians (Catholic and Protestant) and one Hindu. Rose Garden, located in the heart of the city of Palangkaraya, has been long been established as one of the finest schools in the province, and had around 900 students enrolled in 2010. The majority of students were Muslims and Protestants, while Catholics were around 15 students and Hindus were only a few. Averroes is administered by a large Islamic organisation. Its student body was around half the size of that of Rose Garden; all were Muslims except only three Protestant students in 2010.

19 For guidelines of how to conduct qualitative case studies see among others Sharan B. Merriam, Case Study Research in Education: A Qualitative Approach (San Francisco: Jossey-Bass Publishers, 1988); Sharan B. Merriam, Qualitative Research and Case Study Applications in Education (San Francisco: Jossey-Bass Publishers, 1998); Anselm Strauss and Juliet M. Corbin, Basics of Qualitative Research: Techniques and Procedures for Developing Grounded Theory, $2^{\text {nd }}$ ed. (Thousand Oaks: SAGE Publications, 1998); for comprehensive methods of data analysis see Michael Quinn Patton, Qualitative Research and Evaluation Methods, $3^{\text {rd }}$ ed. (Newbury Park: SAGE Publications, 2002); Matthew B. Miles and A. Michael Huberman, Qualitative Data Analysis: An Expanded Sourcebook (Newbury Park: SAGE Publications, 1994). 
St Peter is a Catholic school being the smallest school among the four, which enrolled only 175 students in 2010. Sixty per cent of this student population were Protestants, and one student was Muslim.

It is pertinent here to understand the composition of the population based on religion in the two provinces. In Yogyakarta, Muslims constitute the largest population reaching around $91 \%$ of the total 3,434,534 people in 2007, while Catholic and Protestant were around 8.5\%. The rest of the population consisted of Hindus, Buddhist and Confucians. ${ }^{20}$ In Yogyakarta, Muslims are always dominant in politics with Sultan (the King) of Yogyakarta ex offocio becoming the Governor of the province. Yogyakarta has demonstrated a solid interreligious relations and tolerance. In Central Kalimantan, Muslims formed the majority with over $70 \%$ of 2,131,693 people in 2008. Catholics constituted the second majority with over 15\% followed by around 4\% Protestants, 9\% Hindus, and over $1 \%$ Buddhists and others. ${ }^{21}$ Unlike in Yogyakarta, although Muslims were the majority in Central Kalimantan, they were not strong political players particularly after the current Governor took the office in 2007. The "comeback" of indigenous Dayak after the ethnic violence in 2001 seems to be influential in the declining of Muslim power since most of Dayak are Christians. Although interreligious relation and tolerance in this province has been so far excellent, the political elites often used religion as a means to discredit their political opponents. ${ }^{22}$

I conducted three stints of fieldwork each lasting two months in the four schools, in the period $2009-2010$. With the approval of the Head of Dinas Pendidikan (education office) and the respective principal, I visited each school almost every school day observing and talking with people formally and informally. I conducted ethnographic observations of the day-to-day school practices and events. I wrote in fieldnotes what

20 Statistics of Yogyakarta (2007).

${ }^{21}$ Statistics of Central Kalimantan (2008).

${ }^{22}$ During my fieldwork in Palangkaraya, I have informally talked with several political figures and academics regarding the current socio-cultural and political situations in the province. Some of them are from religious organisation like Indonesian Ulama Council (MUI) who were concerned with the political orientation which, in their view, somewhat benefit Christians significantly. For example, one of them said that Churches have been built in areas where the Christians are a few. The Christian side however rejected this allegation that the development in the province is always based on the philosophy of Rumah Betang (traditional long house) where diverse communities can live together in harmony. So, as one of them (Head of Dinas Pendidikan) said, there is no discrimination of whatsoever. 
I saw activities and what I heard which were relevant and significant for the purpose of the research. I took pictures to document visual activities. I employed Focus Group Discussions (FGD) and in-depth interviews with more than 80 students and 40 teachers and four principals exploring their perspectives on how religious minority access to $\mathrm{RC}$ and what factors support or hinder such access. With their permission, I recorded the conversations to ease the process of data analysis later. I had a research assistant to transcribe all the recorded data, and checked the transcripts carefully to avoid any missing information. In analysing the huge amount of data, I used N-Vivo to generate codes and categorisations so that meaningful interpretations can be made.

\section{Access to RC in State Schools}

As mentioned previously, the Education Law of 2003 mandates that each student has the right to access religious teachings by teachers of the same faith. It is, therefore, the school responsibility to provide qualified teachers for each religion professed by students. The four schools exhibited respective problems particularly in terms of the willingness to provide RC and its facilities. I classify the presentation and discussions of the findings into two categories, i.e. access to RC in state schools and access to RC in private schools.

Rose Garden and Creativity, although they are state schools where religion class is subsidised by the government, had problems with the law implementation. Rose Garden, a home to four religious groups of students: Protestants, Muslims, Catholics, and Hindus, has provided with appropriately qualified teachers for each religion class, but failed to provide equal facilities to each of the groups, particularly to Catholics and Hindus. All religious lessons were allocated in parallel with the convention that, if there were more than one religious group in one classroom, the minority left the classroom for another predetermined classroom. For Muslims and Protestants, who were the predominantly majority, the "another" classroom was readily available, but for Catholic and Hindu students, there was no proper classroom provided where they could comfortably learn their respective religious teachings. Sometimes, these minorities had to study in the shared teacher office which was not at all feasibly useable for teaching activities since it was crowded by teachers' tables and chairs. When the class was held in this office, many teachers were there having conversations with each other, a situation that made 
the teaching process frequently distracted, ineffective and unenjoyable. On another occasion, they were forced to run the class in the schoolyard sitting on one of the benches under the tree. This might create a more relaxed and enjoyable learning process, but it did not seem to be a deliberate choice by either the teacher or students on the consideration of pedagogical effectiveness. Instead, this was because they had to.

Diana, the Catholicism teacher in Rose Garden, explains:

It is difficult for me to organise my class as we have to move from place to place. There is no permanent classroom. Actually, the principal provides access to the school library for us to use during the class, but the place is not representative. We want a permanent one where we can learn comfortably and display our religious identities.

Ni Luh, the Hinduism teacher, also describes the situation as being difficult for religious minorities. She sometimes has to run her class in the school canteen. ${ }^{23}$ She also criticises the school policy not to provide a place of worship for Hindus at the school. The minority Hindu teachers (2 persons) and students have to join their community outside the school for religious congregations. The principal and the vice-principals, however, argued that the school has lack of capacity to accommodate students, and therefore it is difficult to dedicate some classrooms exclusively for these minority groups. They refer to some Islamic classes that are also regularly held in the musalla (prayer room). The Muslim students who joint these classes yet explained that the use of musalla as a learning classroom is not because the absence of the proper classroom, but it is because of the teacher's preference.

Similarly, Creativity provided teacher(s) for every religion of its students. There were one to three minority students in several classroom, and for technical reasons their RC timetable followed that of the Muslim majority. They went out to a specific classroom to have such instruction from their teachers. Catholic and Protestant students had to share the classroom for their religious learning process. Although the room is big enough for only two to five students (Catholic and Protestant students),

${ }^{23} \mathrm{Ni}$ Luh is actually criticised by one of the vice principals for lack of seriousness in teaching. She owns one of the stalls in the school canteen and sells food and drinks to students. She spent much of her time at the canteen since she has no shop assistant. For this reason, she often teaches the few Hindu students in the canteen. There seems to be a blaming game between the teachers of religious minority and the school leaders. But, I have understood in general that the school demonstrates insufficient attention to religious minorities in regards to RC implementation. 
the sharing arrangement could hinder teaching effectiveness because of voice interference of one teaching to another. Christian teachers in Creativity conveyed that they have voiced concerns for a proper classroom and prayer facility for each Protestant and Catholic group. In response to this concern, according to Mr Marjono, the Protestantism teacher, the principal has allocated a new room in addition to the existing one. At the time of fieldwork in 2009, they still used and shared an old classroom for teaching and learning as well as for prayer, but starting in 2010, they would use a new and more suitable room.

The failure to ensure religious minority rights in both Rose Garden and Creativity seems to be very much dependent on the school policy. The financial support from the government might be small, but this lack of financing is also the case for other classes. As admitted by the principals of both schools and the local Education Office figures, the government has also provided teachers for each religion class. From my understanding of both Rose Garden and Creativity cases, there are several factors that contribute to the failure to fulfil the minority rights. One factor is related to the willingness to respect and fulfil minority rights. In my interviews with the principal of each school, there is a positive understanding of religious diversity, but this understanding has not been fully manifest in the school policy, Rose Garden in particular, regarding the religion class arrangement for minority groups. Differently, as indicated earlier, the Creativity principal has worked on ensuring equal opportunity and access for all religious groups to good quality RC. He says:

In general, I can say that my policy is not to make discriminations among religious groups. I always attend each Christian ceremony or celebration in this school, be it Christmas, Easter, or etc. I feel that the school condition [for treating minority] is much better than that during the previous leadership. Previously, the school only provided one classroom for both Catholic and Protestant classes. Now, I provide permanent two classrooms. The new classroom would be fully in use in 2010 .

\section{E. Access to RC in Private Schools}

As mentioned earlier, two of the four schools are private, i.e. Averroes and St Peter. Averroes had three Protestant students in 2009 one female and two males. As a private Islam-based school, this institution applied strict regulations about observing Islamic teachings, including wearing Islamic dress (jilbab) for women regardless of religion. Yet this 
school was open to non-Muslim students. They were informed about such regulations at the time of registration. The school did not provide non-Islamic religion classes for its students nor make it compulsory for non-Muslim students to attend Islamic religion class. They could choose whether to stay or leave the class, but were obliged to learn about their religion at home or in their community. Mrs Fatimah, the Islam teacher, explained:

The school provides a control book on which their priests write their religious attendance and comments. For evaluation, we ask the respective priests to provide assessment of the students.

Markus, one of the Protestant students, conveyed that this rule has forced him to attend the weekly congregation regularly. He admitted that sometimes he was lazy or reluctant to go, but he had to, otherwise the priest would not provide him with a good report to the school. Mr Yamin, the principal, argued that it is very costly to provide Protestantism Class if there are only a couple of students. He said: "the cost of one class with three students is no difference with the cost of one class with twenty or thirty students". He continued that by requiring the minority students to access RC in their community the school has not turned away from the Law of 2003 mandate. Instead, as he argued, the school tries to compromise between the law requirement and the pragmatic problem the school is faced. In the rapport, the students received the marks of Protestantism class from their priest. The Islamic religion teachers were responsible to communicate with the priests.

St Peter, the Catholic school in Central Kalimantan, applied a sweeping policy to teach Catholicism to all students regardless of their religious affiliations. As described before, the student population in 2009 was only 175 students, and the majority of them are from Protestant background as so the teachers are. Most of the students interviewed indicated their acceptance to the school policy of this mono-religious RC. Before they decided to choose this school, they had been aware of this policy. As they admitted, they could do nothing regarding this school policy. They knew at the very beginning the consequence of choosing this school, but they prefer quality to RC. St Peter has established a good reputation of providing a good quality education and discipline. For this quality reason, the Yayasan keeps the number of new students accepted in the school low.

According to Sr Angela, the Catholicism teacher, although all 
students were obliged to learn Catholicism and participated in all the religious activities, there was no intention to convert them to Catholicism. The Catholic religion class was merely delivered as a mandate from the school Yayasan. Many students admitted that they learn the Catholic religion for the matter of school obligation only. They had to pass the subject examination since the class was compulsory and determining their grade promotion. During the FGD, many Protestant students explained that they never take the lessons personally in a way that these change their existing beliefs. But they admitted that there is a positive side of the RC in St Peter, which is to understand more about Catholicism so that they were aware of the differences from their faith. Vicky, one of the Protestant students, described how he was confused before making decision on which school to go after the junior secondary graduation. He said:

Initially, I think it is weird for a Protestant like me going to a Catholic school. I went to consult with Andik, who has been my best friend since primary school. [I asked]: "Dik, if you go to the Catholic school, would this create a problem to you as a Muslim?" [Andik answered]: "Yes, of course. I think I am going to withdraw". But I said: "Please, don't withdraw. If you turn away from the school, who will then become my friend?" So we decided to go. At the beginning, I kept thinking of how the religious lesson later on; will I be converted to Catholicism? But as the time goes, this has not happened. Instead, I learn a lot about Catholicism.

Andik, the only Muslim student, says:

At school, I only learn the Catholic teachings and do some practices. We go to Church regularly to pray. When the teacher requires me to memorise prayers, I do it. No problem. The most important thing is that I get good marks for the class.

When I asked him whether he practices the teachings at home, Andik says, "No. I don't practice the prayers at home because I am a Muslim." His school also does not provide him with a musolla or a room for praying in Islamic ways during the school hour.

As we can infer from the above findings, Averroes and St Peter cases are different from Rose Garden and Creativity. The state schools received supports from the government in regards to the religion class arrangement especially the provision of religion teachers, while the private ones did not, according to the principals of Averroes and St Peter. While Mr Yamin, the Averroes principal, mentioned the cost as a reason for 
justifying the absence of RC for the minority students, Mrs Anti, the principal of St Peter, confirmed that the mission of her Catholic school is to teach Catholicism to people. She argued further that as a private school, St Peter had the right to be exclusive, but she failed to provide a legal basis for this argument.

\section{F. Teachers' Perspective of the Education Law of 2003}

The above presentation reveals several problems of the implementation of the Education Law of 2003 in regards to RC. In state schools, the problems are centred at the unequal treatment of RC for majority and minority groups. Majority groups enjoy the privileges of being dominant and hence access better provision of RC, whilst minority groups are bounded within powerlessness, and under the domination of the "ruling" majority. In private schools, the belief that private religious schools have the freedom to provide their own RC remains strong particularly in the case of St Peter. While the leaders of the schools (Averroes and St Peter) are aware of the Law of 2003, they also insist on applying what best suit their interests. However, the religion teachers of the four schools who are with students in day-to-day classroom practices were unanimously in agreement with the particular article of the Education Law of 2003. They believed that schools have to provide religion class according to students' religion taught by teachers of the same religion. I quote here comments of each $\mathrm{RC}$ teacher in the four schools.

Sr Angela of St Peter: I am aware of the Law and fully agree with it. I have encountered difficulty in teaching Catholicism to students here. The majority of them are not Catholics. I feel confused sometimes. That's why I often modify my teaching strategies to suit their backgrounds. For example, I sometimes ask them to go to their religious teachers in the community to ask about the topic being discussed in the classroom.

Mrs Fatimah of Averroes: We fully support the implementation of the Law of 2003 that students should receive religious lessons according to their own religions. That's why we do not require the minority students to attend the Islam class. Instead, we ask them to learn (their religious lessons) from their priests in the community.

Mrs Diana of Rose Garden: I think what the government issued regarding the regulation of religious education should be praised. 
Now, the implementation remains problematic. Like what you see here in this school, minority groups do not have equal access to RC. We are so differentiated from the majority.

Mr Yohannes of Creativity: The Education Law of 2003 is very good. It guarantees our minority rights to access religious teachings in the Muslim majority schools. I can't imagine sending my children to Islamic schools and they learn Islamic religions instead of Catholic teachings. It is a terrible mistake for parents. [...] Those who oppose the [particular article of the] Law don't understand it fully.

Mr Marjono of Creativity: I agree with the Law. Even after the Law was issued as we have now, we as minority in this school are still struggling for our rights to have equal provision of religious education.

The teachers further conveyed that the Law ensures that religious rights of children are maintained, parents feel safe, and suspicions among religious groups can be minimised. The suspicion about "Islamisation" and "Christianisation" by Christian and Muslims respectively has emerged during the history of the modern Indonesia. The education has become one of the "battlefields" where each group has played and exercised influence. The report by the International Crisis Groups in 2010 suggests that there is a strong competition between aggressive Christian evangelists who are committed to convert Muslims and Islamic organisations to counter what so-called "Christianisation". ${ }^{24}$ This competition has contributed to the heating of Muslim-Christian relations and religious intolerance in recent years.

It is clear that the teachers did not problematise the issue of the Education Law of 2003, in particular regarding Article 12 about the rights of students to access religious education in school. Non-Muslim minority

24 'Indonesia: 'Christianisation' and Intolerance”, International Crisis Group (23 Oct 2011), http://www.crisisgroup.org/en/regions/asia/south-east-asia/indonesia/ B114-indonesia-christianisation-and-intolerance.aspx, accessed 23 Oct 2011. The report says: "On the Christian side, several evangelical organisations committed to converting Muslims have also set up shop in Bekasi, some funded internationally, others purely home-grown. Yayasan Mahanaim, one of the wealthiest and most active, is particularly loathed by the Islamist community because of its programs targeting the Muslim poor. Another, Yayasan Bethmidrash Talmiddin, run by a Muslim convert to Christianity, uses Arabic calligraphy on the cover of its booklets, suggesting they are Islamic in content, and requires every student at its school as a graduation requirement to convert five people". 
teachers viewed the importance of the Law in maintaining religious interest and welfare of children. This contradicts the claims of several groups that the particular article of the Law would not take the side of minority groups. Conversely, in this study, the religious minority groups within the micro school level believed that the Law can be a protector of their rights from the majority oppression if its implementation goes well.

\section{G. Education for Minority}

What has been presented above indicates, to a worrying degree, problems of the RC implementation for religious minority groups in Creativity, Rose Garden, Averroes and St Peter. The problems reflect one big underpinning factor, which is lack of recognition or misrecognition. These schools failed to recognise the existence of this specific culture of these minority students and their rights as they did to the majority cultures. Taylor consistently relates that the lack of recognition "can inflict harm, can be a form of oppression, imprisoning someone in a false, distorted, and reduced mode of being". 25 The cases above also show structural marginalisation by the schools as social institutions which caused the feeling of being discriminated in students. The minority groups in the four schools have experienced this discrimination in a way that put them into a powerless condition to accept a kind of social and cultural injustice. ${ }^{26}$ Samuel, a Catholic student in Rose Garden, describes:

Yes, we feel treated unjustly here particularly in the matters of classroom for our religion class and place of worship. But, we understand that we are minority here, and we have to understand that the school is in the

25 Taylor, "The Politics", p. 25.

26 Alan Cribb and Sharon Gewirtz, "Towards a Sociology of Just Practices: An Analysis of Plural Conceptions of Justice", in Social Justice, Education and Identity, ed. by Carol Vincent (London: Routledge Falmer, 2005), pp. 15-29. Power and Gewirtz identify three types of justice: distributive, cultural and associational. Distributive justice as previously defined will be possible only if the absence of exploitation, marginalisation, and deprivation can be ensured. Cultural justice occurs when every culture in society is valued and recognised to the extent that there is no cultural domination and no disrespect to any culture. Associational justice is seen as: "the absence of patterns of association amongst individuals and amongst groups which prevent some people from participating fully in decisions which affect the conditions within which they live and act." Sally Power and Sharon Gewirtz, "Reading Education Action Zones", Journal of Education Policy, vol. 16, no. 1 (2001), p. 41. These three types of justice cover issues that may arise among those who are dissatisfied with a broad range of social conditions, including economic, cultural, and political conditions, and relations amongst individuals as well as between groups. 
side of the majority.

Further reflecting this lack of recognition by the schools is the absence of the minority groups in the four schools in expressing their religious identity, for instance, during the raising flag assembly on Mondays. At the end of this weekly assembly, one student recites the prayers, while others repeat after him or her or just say "amen". The practice of the four schools suggests that only the majority recited the prayer in their own religious way. In Rose Garden, it is either Protestants or Muslims who lead to recite prayers. In Creativity and Averroes, Muslims always did that job, and in St Peter Catholics did so. Misrecognition of the minority rights have clearly impeded some of their identity from being expressed in the schools' public spaces. Besides, it also undermines some of the basic principles of multicultural schools, i.e. equal opportunity and social justice. ${ }^{27}$

In the context of micro school level, the practice of misrecognition of minority rights in the four schools is influenced greatly by the school leadership and/or Yayasan leadership in the case of private schools. Interviews with the principals and vice-principals reveal that they generally have recognised minority groups as equal members of Indonesian society. All the principals, but that of St Peter, agreed said that minority groups deserve equal respect and opportunity to access $\mathrm{RC}$ as required by the Law. However, equal respect and opportunity in practice were translated into several meanings. In Creativity, the principal tried to provide better learning facilities for the minority Christian students such as allocating another room so that Catholic and Protestant students can learn religious lessons separately. In Rose Garden, the principal insisted on having done sufficiently for minority groups through the provision of impermanent classrooms for RC for Catholic and Hindu students. In Averroes, the principal admitted for not being able to provide the required RC for financial reasons. He regretted this situation and acknowledged such a particular article of the Law of 2003. Differently, while acknowledging the law, the principal of St Peter believed that it is the right of a private religious school not to provide corresponding $\mathrm{RC}$ for non-Catholic students. When she was asked of whether this policy went against the children's rights and the principles of tolerance, she was convinced that it is the policy of the Yayasan and parents already understood the risk.

${ }^{27}$ Christine I. Bennett, Comprehensive Multicultural Education: Theory and Practice (Boston: Allyn and Bacon, 1995). 
All of this information suggests the power of school leaders in shaping policies in regards to religious minorities. The Creativity principal, who was considered by teachers and students as a tolerant individual, was able to demonstrate much better treatment to religious minorities. During formal and informal conversations as well, he has shown ability to discuss the discourse of multiculturalism, the topic of which for the other principals is new.

The findings also reflect the broader macro context, i.e. how the Indonesian state has dealt with the rights of minority groups. Many cases which involve minority groups often suggest the failure of the state to recognise their rights in proper ways. As mentioned early in this paper, the most recent case of Jemaat Ahmadiyah demonstrates how lenient the government towards the anarchist groups who undermine the principles of human rights and multiculturalism. The widespread video footage that can be accessed through youtube.com clearly suggests the brutality of these groups in what they term as correcting the wrongs. To put this into perspective, Hikayat Budiman rightly argues that the government has since the New Order been concerned with unity rather than diversity which is the inherent characteristics of Indonesian society. ${ }^{28}$ The government policies in managing such diversity are focused on uniting and assimilating minorities into the national, which often means majority, culture. ${ }^{29}$ In this context, civic equality which is one of the main characteristics of a democratic society is absent. What comes to the fore then has been the resistance and distrust of minority groups to the government. ${ }^{30}$

In addition, the findings describe the complex and dynamic relations between minority and majority in Indonesia. Despite the hard works done by several groups of both sides through interfaith dialogues and social works, suspicions of each other's activism remain strong particularly as represented by recent cases or conflicts between majority and minority groups. The government has struggled to manage this relation through several laws. Recently, the government has completed the draft of Religious Harmony Law (Undang-Undang Kerukunan

${ }^{28}$ See the Introductory chapter of his book, Hikayat Budiman (ed.), Hak Minoritas: Ethnos, Demos, dan Batas-Batas Multikulturalisme (Jakarta: The Interseksi Foundation, 2009), pp. 1-36.

29 Christine Drake, National Integration in Indonesia: Patterns and Policies (Honolulu: University of Hawaii Press, 1989).

${ }^{30}$ Irwan Abdullah, Konstruksi dan Reproduksi Kebudayaan (Yogyakarta: Pustaka Pelajar, 2006), pp. 63-79. 
Umat Beragama) and submitted to the Parliamentary House. Despite the spirit of this law to manage more harmonious relations among religious groups, the law has not been free from criticisms. The main criticism is regarding the place of religious minority groups vis-à-vis the majority. This does not always mean between Christian or other minorities and Muslim majority, but include - and this would probably be more problematic - minority sects in one religion. The allegation of blasphemy can be lightly used to groups who are considered as deviating from the mainstream. Also, the naming of the law after "Kerukunan" may imply restrictions on religious followers, which contradict the principles of religious freedom. ${ }^{31}$ However, the proponent of this law, for instance Nasaruddin Umar, argues that this law is intended to create better harmonious Indonesian society since the current society is not yet an ideal one which can operate smoothly without laws. ${ }^{32}$ Therefore, as he continues, restrictions on religious activism by religious followers should be understood within the frame of this objective for freedom and rights are always balanced with duties. ${ }^{33}$

\section{H. Concluding Remarks}

This paper has discussed an important aspect of the fulfilment of human rights in a Muslim majority country, Indonesia, i.e. religious minority rights to access $\mathrm{RC}$ in accordance with their own conviction. The practice in the four studied schools, Creativity, Rose Garden, Averroes and St Peter, suggests that minority groups are generally restricted to

31 Dwi Rubiyanti Kholifah, "Nasib Minoritas dalam RUU Kerukunan Umat Beragama", Amanindaonesia (11 Feb 2011), http://amanindonesia.org/ discourse/2011/11/02/nasib-minoritas-dalam-ruu-kerukunan-umat-beragama-.html, accessed 2 Jan 2012.

32 "RUU Kerukunan Umat Beragama Dibahas 2011", Antaranews (23 Sep 2010), http://www.antaranews.com/berita/221819/ruu-kerukunan-umat-beragamadibahas-2011, accessed 2 Jan 2012.

33 Abdullah, "Human Rights", in Australia in Asia: Comparing Cultures, ed. by Anthony Milner and Mary Quilty (Oxford: Oxford University Press, 1996), pp. 44-68. In this chapter, the authors differentiate between individualist and collectivist perspective on human rights. They argue that Asian values differ from Western values in that the former are more communal and family oriented than the latter, and that rights and duties of citizens should be balanced. Therefore, social and economic rights of society may override civil and political rights of individuals. So, in this perspective, justice to individuals meaning to grant all their rights might not necessarily mean justice to the whole society. See Aat Emile Vervoorn, Re Orient: Change in Asian Societies, 3rd edition (Oxford: Oxford University Press, 1998). 
gain access to RC. In the state schools, the fulfilment of this particular right does not fully satisfy the minority groups. While both schools should be applauded for the provision of qualified teachers, they have generally failed to provide proper learning facilities equal to what the religious majority receive. The assumption that majority receive more than minority do seems to be quite strong in these state schools. In the other context, the private schools do not provide the minority groups at all with their own religious education. The difference between Averroes (an Islam-based school) and St Peter (Catholic school) is that Averroes demonstrates a particular concern of this issue by requiring the minority students to attend religious education in Church, obtaining the assessment outcomes from the priests, and not obliging them to attend the Islamic RC. Meanwhile, St Peter sets a sweeping policy that all students regardless of religion have to participate in the Catholic RC and sit in the exam. In both state and private schools, minority groups regardless of religions suffer from improper recognition and hence the majority domination. Worse than this, in St Peter, the case demonstrates that the power of an institution can stifle the rights of people who "forcibly" submit themselves under its authority, regardless if the people are majority or minority in number. This supports the theory that minority does not always mean fewer in numbers, ${ }^{34}$ but can mean in some contexts subordinate majority under the domination of the institutionalised power of minority.

There is absolutely a need to improve the implementation of RC for religious minority groups in schools. The education authority should oversee this implementation to ensure that the rights of every individual in Indonesia are fulfilled. Many individuals of minority groups may not have the heart to express concerns about their right fulfilment as they tend to accept powerlessly their status as minority. Therefore, active consultations by the authority should become one of the education office programs. Also, training for professional development of school leaders as decision makers to improve their understanding and competences in managing cultural and religious diversity in schools should be held regularly with clearer objectives and evaluation. From the findings, I have not found any information from either the school or the corresponding Dinas Pendidikan that the principals have participated in multiculturalismoriented professional development programs. Finally, if the respective and corresponding $\mathrm{RC}$ has been taught to all students, there is a need for comparative approach to RC at least in one or more topics of each of RC

${ }^{34}$ Schaefer, Racial and Ethnic Groups. 
Minority Right to Attend Religious Education in Indonesia curricula. This will serve to bridge understanding of different religious groups about respective religious teachings, and in turn, to nurture tolerance amongst them. Implementing a total comparative religion class does not seem to be viable in the context of school education in Indonesia since $\mathrm{RC}$ is aimed at educating students to become pious and devout followers, or using confessional approach. 
Raihani

\section{BIBLIOGRAPHY}

Abdullah, "Human Rights", in Australia in Asia: Comparing Cultures, ed. by Anthony Milner and Mary Quilty, Oxford: Oxford University Press, 1996.

Abdullah, Irwan, Konstruksi dan Reproduksi Kebudayaan, Yogyakarta: Pustaka Pelajar, 2006.

Alan Cribb and Sharon Gewirtz, "Towards a Sociology of Just Practices: An Analysis of Plural Conceptions of Justice", in Social Justice, Education and Identity, ed. by Carol Vincent, London: Routledge Falmer, 2005.

Bayuni, Endy, Blood Blasphemy: Antagonising Religious Minorities in Indonesia and Pakistan, New York: Washington D.C. East-West Center, 2011.

Bennett, Christine I., Comprehensive Multicultural Education: Theory and Practice, Boston: Allyn and Bacon, 1995.

Budiman, Hikayat (ed.), Hak Minoritas: Ethnos, Demos, dan Batas-Batas Multikulturalisme, Jakarta: The Interseksi Foundation, 2009.

Cesari, Jocelyn, "Islam in France: The Shaping of a Religious Minority", in Muslims in the West, from Sojourners to Citizens, ed. by Yvonne Yazbeck Haddad, New York: Oxford University Press, 2002.

Crouch, Melissa, "Regulation on Places of Worship in Indonesia: Upholding the Right to Freedom of Religion for Religious Minorities?”, Singapore Journal of Legal Studies, vol. 2007, 2010.

Departemen Pendidikan Nasional, Undang-Undang Sistem Pendidikan Nasional Tahun 2003.

Drake, Christine, National Integration in Indonesia: Patterns and Policies, Honolulu: University of Hawaii Press, 1989.

"France Bans the Burqa", SBS, 29 Aug 2013, http://www.sbs.com.au/ news/article/2011/04/11/france-bans-burqa, accessed 23 Oct 2013.

Grimmitt, Michael H., Religious Education and Human Development: The Relationship Between Studying Religions and Personal, Social and Moral Education, Great Wakering: McCrimmon, 1987.

Husaini, Adian, "Membela Pendidikan Agama", Republika, Jakarta, 15 Mar 2003, https://groups.yahoo.com, accessed 15 Jan 2005.

Indonesia: "Christianisation' and Intolerance", International Crisis 
Minority Right to Attend Religious Education in Indonesia

Group, 23 Oct 2011, http://www.crisisgroup.org/en/regions/asia/ south-east-asia/indonesia/B114-indonesia-christianisation-andintolerance.aspx, accessed 23 Oct 2011.

Kelabora, Lambert, "Religious Instruction Policy in Indonesia", Asian Survey, vol. 16, no. 3, 1976 [http://dx.doi.org/10.2307/2643542].

Kholifah, Dwi Rubiyanti, "Nasib Minoritas dalam RUU Kerukunan Umat Beragama", Amanindaonesia, 11 Feb 2011, http://amanindonesia. org/discourse/2011/11/02/nasib-minoritas-dalam-ruu-kerukunanumat-beragama-.html, accessed 2 Jan 2012.

Kymlicka, Will, Multicultural Citizenship: A Liberal Theory of Minority Rights, New York: Oxford University Press, 1995.

Listia, Laode Arham, and Lian Gogali, Problematika Pendidikan Agama di Sekolab: Hasil Penelitian tentang Pendidikan Agama di Kota Jogjakarta, 2004-2006, Yogyakarta: Interfidei/Dian, 2007.

Macedo, Stephen, Diversity and Distrust: Civic Education in a Multicultural Democracy, Cambridge: Harvard University Press, 1999.

Mandaville, Peter, "Islamic Education in Britain: Approaches to Religious Knowledge in a Pluralistic Society", in Schooling Islam: The Culture and Politics of Modern Muslim Education, ed. by Robert W. Hefner and Muhammad Qasim Zaman, New Jersey: Princeton University Press, 2007.

Merriam, Sharan B., Case Study Research in Education: A Qualitative Approach, San Francisco: Jossey-Bass Publishers, 1988.

Merriam, Sharan B., Qualitative Research and Case Study Applications in Education, San Francisco: Jossey-Bass Publishers, 1998.

Miles, Matthew B. and A. Michael Huberman, Qualitative Data Analysis: An Expanded Sourcebook, Thousands Oaks: Sage Publications, 1994.

Mujiburrahman, Feeling Threatened: Muslim-Christian Relations in Indonesia's New Order, Amsterdam: Amsterdam University Press; ISIM, 2006.

Multicultural Australia: United in Diversity, Updating the 1999 New Agenda for Multicultural Australia, Strategic Directions for 2003-2006, Canberra: Dept. of Immigration and Multicultural and Indigenous Affairs, 2003.

Parekh, Bhikhu, Rethinking Multiculturalism: Cultural Diversity and Political Theory, 2nd ed., New York: Palgrave Macmillan, 2005.

Patton, Michael Quinn, Qualitative Research and Evaluation Methods, 3rd ed., Al-Jāmi‘ah, Vol. 53, No. 1, 2015 M/1436 H 
Raihani

Newbury Park: SAGE Publications, 2002.

Power, Sally and Sharon Gewirtz, "Reading Education Action Zones", Journal of Education Policy, vol. 16, no. 1, 2001 [http://dx.doi. org/10.1080/02680930010009813].

Raihani, "Religion Classes in Indonesia: Translating Policy into Practice", presented at the the Crises and Opportunities: Proceedings of the 18th Biennial Conference of the ASAA, Adelaide: University of Adelaide, 8 May 2010.

RUU Kerukunan Umat Beragama Dibahas 2011”, Antaranews, 23 Sep 2010, http://www.antaranews.com/berita/221819/ruu-kerukunanumat-beragama-dibahas-2011, accessed 2 Jan 2012.

Schaefer, Richard T., Racial and Ethnic Groups, New York: Longman, 1998.

Taylor, Charles, "The Politics of Recognition", in Multiculturalism: Examining the Politics of Recognition, ed. by Amy Gutmann, New York: Princeton University Press, 1994.

UN General Assembly, International Covenant on Civil and Political Rights, vol. 999, United Nations Treaty Series, 2012, http:/ / www.refworld.org/ cgi-bin/texis/vtx/rwmain?docid=3ae6b3aa0, accessed 30 Jan 2015.

United Nations, Minority Rights: International Standards and Guidance for Implementations, New York: United Nations, Human Rights Office of the High Commissioner, 2010.

Vervoorn, Aat Emile, Re Orient: Change in Asian Societies, 3rd ed., Oxford: Oxford University Press, 1998. 